\title{
ANALYSIS OF STUDENT SCIENTIFIC LITERACY: STUDY ON LEARNING USING ETHNOSCIENCE INTEGRATED SCIENCE TEACHING MATERIALS BASED ON GUIDED INQUIRY
}

\author{
Sakila Wati*, Agil Al Idrus, and Abdul Syukur \\ Magister of Science Education, Postgraduate Studies, University of Mataram. \\ *Email: sakila.we21@gmail.com
}

Acceped: Nov 11 2021. Approved: Nov 11 2021. Published: Nov 142021

\begin{abstract}
There are still few teachers who develop their teaching materials independently. There is also no continuity in science learning between scientific knowledge with real-life problems and local wisdom. As a result, learning is less meaningful, and students' scientific literacy skills remain low. This study aims to develop ethnoscience integrated science teaching materials based on guided inquiry that are appropriate and effective in improving students' scientific literacy. This study is development research that refers to the $4 \mathrm{D}$ development model. In addition to developing ethnoscience integrated science teaching materials based on guided inquiry, the researchers also developed syllabus, lesson plan, and students' scientific literacy instrument. The data collection technique used a validation sheet by three expert lecturers who are competent in their fields to measure the feasibility of the teaching materials. The scientific literacy instrument used multiple-choice questions. The data analysis technique used the validation percent index and the $\mathrm{N}$-gain test to determine the increase in scientific literacy. Thi study obtained: 1) ethnoscience integrated science teaching materials (90); 2) syllabus (93); 3) lesson plan (90); and 4) scientific literacy instrument (90) with very valid and valid criteria; and revealed that 5) ethnoscience integrated science teaching materials can improve students' scientific literacy, as evidenced by the average score obtained by three schools with high improvement criteria. To summarize, this ethnoscience integrated science teaching materials based on guided inquiry are feasible and effective to be applied and implemented in learning to improve students' scientific literacy.
\end{abstract}

Keywords: analysis, scientific literacy; science teaching materials; ethnoscience; guided inquiry

\section{INTRODUCTION}

The development of teaching materials is one of the processes that need to be considered [1]. Teaching materials are tools that can support the implementation of learning [2]. The performance of learning at every level of education is required to provide teaching materials that can facilitate students' learning activities [3].

Teaching materials are learning resources that direct students to obtain information, knowledge, experience, and skill more easily in the teaching and learning process [4]. The arrangement of teaching materials influences the complexity of teaching materials obtained by students in each lesson. Therefore, high-quality teaching materials can help students learn more effectively and efficiently and improve their learning quality [5].

One of the issues that persist in schools is the lack of teaching materials that allow students to learn independently. Students tend to wait for the teacher to find the concept since they do not have the opportunity to learn actively and independently [6].

Based on field studies, science learning in junior high schools in East Lombok Regency has used the 2013 curriculum, and educators' learning has led to a scientific approach. Planning for the implementation of learning has been made following the demands of the 2013 science curriculum, but learning activities are still heavily reliant on textbooks. Teachers have not developed teaching materials, and students are still focused on textbook concepts, so the objectives of contextual learning, which is learning in the context of the students' real world, have not been met. According to [7], science learning is very close to everyday life and can be found in the surrounding environment so that students can use the environment as a learning resource. Students become unfamiliar and motivated to learn new things due to learning that is still based on textbooks. The knowledge gained by students through experimentation is still based on previous conclusions. Teachers still have a hard time connecting real-world scientific concepts to the material they're teaching. This learning pattern does not adequately describe 21st-century learning because it does not fully cover aspects of scientific literacy.

Appropriate learning strategies, such as determining learning models and developing teaching materials that support students in mastering scientific literacy, are used to improve students' scientific literacy. The guided inquiry learning model has been studied and found to be appropriate in this case. The development of ethnoscience integrated teaching materials is a step toward increasing students' creativity. Rather than only focusing on a deep understanding, ethnoscience integrated learning focuses on achieving an integrated understanding. Ethnoscience refers to organized learning within a local culture and wisdom knowledge system [8]. According to [9], in ethnoscience learning, students connect the subject 
matter studied with the context in their lives and the relationship with science and technology so that education in schools is not only informative but also practical and helpful in students' lives. Ethnoscience integrated learning is a learning approach that does not separate science, culture, and local wisdom [10]. According to [11], the recommended scientific approach for education in Indonesia today is ethnoscience, or actual knowledge in the form of language, customs, culture, morals, and technology created by certain societies or people containing scientific knowledge.

Several studies have found that the relationship between science and culture impacts students' academic performance [12]. [13] found that learning tools that use guided inquiry models can help students improve their higher-order thinking skills. Other research findings demonstrating the success of local culture integrated learning, such as research on the effectiveness of local culture integrated learning, show that students learn more meaningfully [14].

\section{RESEARCH METHOD}

This study is development research based on the 4D development model. In addition to science teaching resources, researchers develop syllabus, lesson plan, and scientific literacy test instrument. This study was conducted at three junior high schools in the East Lombok Regency.

Three expert lecturers validated the learning tools by filling out a validation sheet. Furthermore, the validators are required to provide assessments and general suggestions on the developed ethnoscience integrated science teaching materials based on guided inquiry, including whether the teaching materials created are valid. Multiple-choice tests were used to gather data on scientific literacy. Expert validation data were analyzed to assess the level of validity using the percent validation formula. Data analysis was used to determine the effectiveness of science teaching materials developed using the N-Gain test.

\section{RESULT AND DISCUSSION}

Ethnoscience integrated science teaching materials based on guided inquiry attempt to create environments that encourage learning by connecting culture and science material packaged in ethnoscience. In addition, ethnoscience integrated science teaching materials encourage students to interact directly with local culture and investigate the knowledge (science) that exists there.

Science will be easier to understand if the teacher pays attention to the students' culture [15]. Teachers' understanding of learning wisdom can make science learning more meaningful, so teachers need to know the actual combination of knowledge in society with scientific knowledge in school [16].
Integrating culture into learning is essential because twenty-first-century learning in schools is science learning with a multicultural approach [17]. As a result of this condition, teachers take an important role, especially in developing knowledge of teaching materials integrated with local wisdom to improve students' higher-order thinking skills.

Local wisdom integrated teaching materials developed in this study is the interaction of living things with the environment. In their application, these teaching materials can teach students about traditions and the culture of preserving the environment. According to [18], tradition and culture protect the environment to continue functioning and provide benefits, particularly to the community and the surrounding ecosystem.

Teaching materials delivered by the teacher should instill character education in students through culture and local wisdom integrated with the concepts they aim to learn so that students can think scientifically about the phenomena they encounter daily. One way to incorporate learning based on local wisdom is by developing teaching materials based on ethnoscience [19]. Local wisdom is applied in science learning by incorporating a culturespecific to East Lombok Regency. Natural science teaching materials are integrated with the local one. Local wisdom-based educational materials are an assimilation of scientific knowledge and actual knowledge [20].

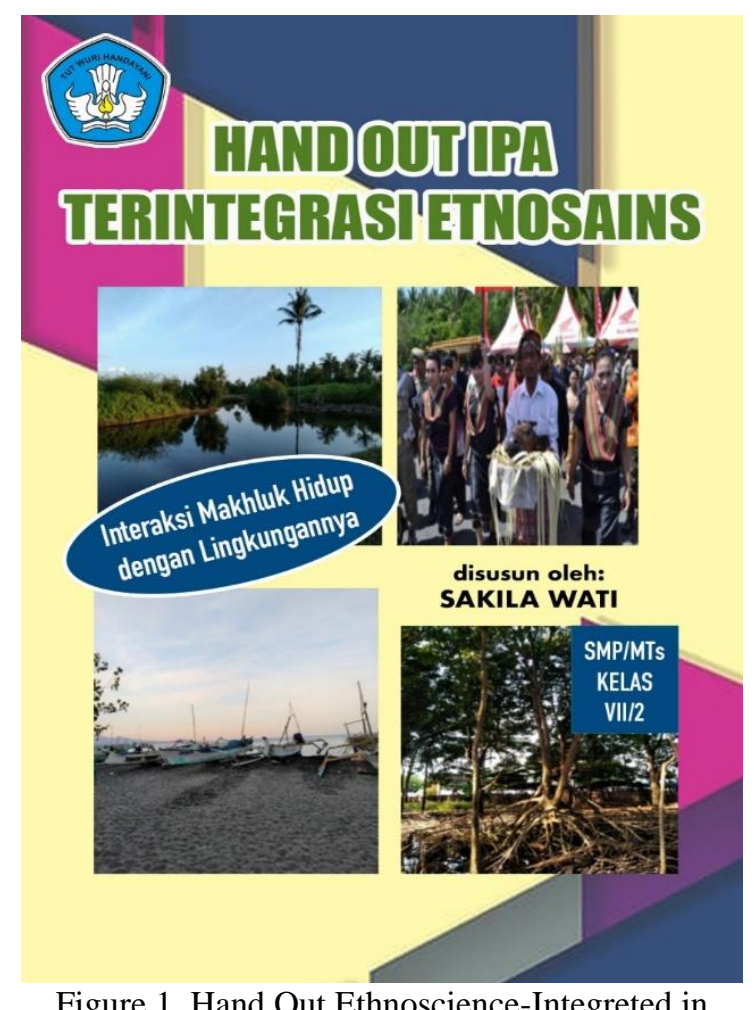

Figure 1. Hand Out Ethnoscience-Integreted in Science Learning 


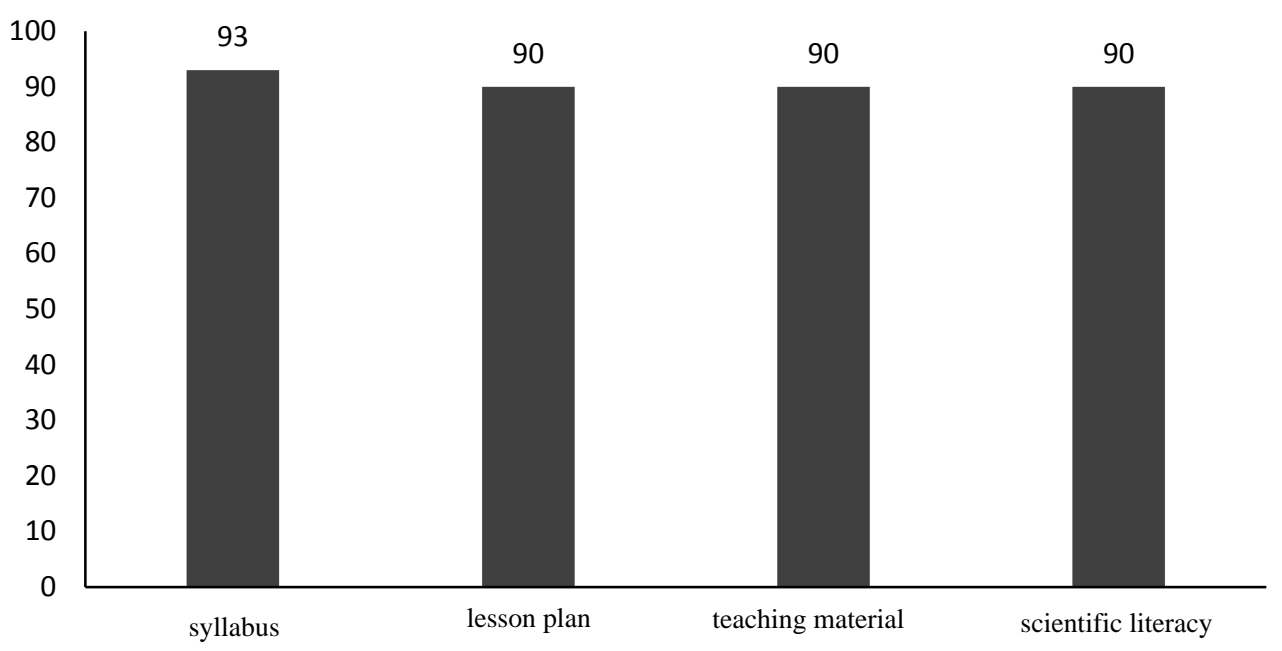

Figure 2. Learning device validation results.

This study successfully developed ethnoscience integrated science teaching materials based on guided inquiry to improve students' scientific literacy. This research employs a 4-D model that focuses on the development stage, which includes validity testing. The stages of determining and designing are the first steps in the development of teaching materials.

Three experts with expertise in their fields carry out product validation following the development of science teaching materials. Figure 2 shows the results of the expert validation that were obtained.

Based on Figure 2, the syllabus received an average score of $93 \%$ with very valid criteria. In contrast, lesson plan, teaching material, and scientific literacy instruments received an average score of $90 \%$ with very valid criteria. This indicates that the ethnoscience learning tool based on guided inquiry is appropriate for science learning. Overall, it demonstrates that teaching materials that a group of experts has validated are in the proper category for learning. Teaching materials developed after the validation stage are feasible to be tested in learning. The developed teaching materials can be found in the appendix.

Learning using ethnoscience integrated science teaching materials based on guided inquiry also allows students to be directly and actively involved in scientific activities, as well as provide direct experience with science learning in the context of ethnoscience so that students can remember the concepts easier and they gain a better understanding of the material being studied. This is in line with what was stated by [21]. High learning outcomes usually accompany high levels of activity.

After examining the feasibility of ethnoscience integrated science teaching materials based on guided inquiry, the normalized gain test was used to assess the effectiveness of science teaching materials in improving scientific literacy. Table 1 displays the results of the normalized gain test.

Table 1. Results of Student Scientific Literacy Assessment

\begin{tabular}{llcccc}
\hline No & \multicolumn{1}{c}{ School } & $\begin{array}{l}\text { Average } \\
\text { Pretest }\end{array}$ & $\begin{array}{c}\text { Average } \\
\text { Posttest }\end{array}$ & N-gain & N-gain Criteria \\
\hline 1. & $\begin{array}{l}\text { State Junior High School 1 } \\
\text { Pringgabaya }\end{array}$ & 42.06 & 85.78 & 76.29 & High \\
2. & $\begin{array}{l}\text { State Junior High School } \\
\text { Pringgabaya }\end{array}$ & 38.33 & 82.82 & 72.68 & High \\
3. & $\begin{array}{l}\text { Islamic Junior High School NW. } \\
\text { Pringgabaya }\end{array}$ & 35.41 & 82.50 & 73.14 & High \\
Average & 38.60 & 83.70 & 74.04 & \\
\hline
\end{tabular}

Table 1 shows that, in the experimental class, the average pretest score for students was 38.60 , while the average posttest score was 83.70 showing a significant increase. The increase in students' scientific literacy skills met high criteria with an average $\mathrm{N}$-gain value of 74.04 .
The increase in students' scientific literacy after using these teaching materials is due to the description of the material in the teaching materials packaged by displaying scientific contexts. Based on the displayed science context, students ask questions. Questions posed by students show their curiosity to acquire new knowledge through 
investigation activities. Students perform scientific processes such as making observations, collecting data, interpreting, predicting, concluding, and communicating during the investigation. These investigation activities (inquiry) must be taught to students to expand their knowledge and improve their learning outcomes [22]. Students become accustomed to thinking processes and scientific activities, resulting in increased mastery of concepts and competencies. This is consistent with Puspitasari et al. [23], who found that context-based inquiry learning can improve students' conceptual proficiency. Students are adept at bridging the gap between everyday experiences and classifying and organizing the subject matter. Students' mastery of concepts, science process skills, and thinking can be improved by using inquiry activities in the classroom [24].

Ethnoscience integrated science teaching materials could provide a new learning experience for students. Students become more engaged in the learning process as a result of the newly developed teaching materials. The developed handout includes a series of material summaries and pictures, and questions to encourage students to solve problems/phenomena presented through videos, pictures, or the surrounding environment to improve their ability to explain phenomena scientifically. Students' abilities describe their success in the learning process, which impacts their scientific literacy. The results obtained by students after working on the posttest questions demonstrate their scientific literacy. The multiple-choice questions are accompanied by phenomena relating to the interaction of living things with their environment relevant to students' experiences. Students' experience assists students in working on questions by remembering the practicum they completed instead of memorizing the textbooks. This is enough to assist students in working on the questions because they will remember what they did during the practicum more. The practicum method guides the students to directly observe, prove, understand, absorb, and observe what they learn and do.

Science education should be aligned with its function and goal, which is to instill a scientific mindset in students. When laboratory research demonstrates that students are curiously focused on the learning process, they are independently happy, enthusiastic, and motivated to participate in learning [25]. This indicates that students are engaged in the learning process. Furthermore, students can work well in groups and engage in democratic debate during group activities. Learning is studentcentered, and students become very active because they can be directly involved in learning [26].

Suitable teaching materials include interactions between science, technology, and society. This interaction aims to give a broad overview of science's influence or impact on society [27]. The aspect of scientific literacy refers to the implementation or application of science and how technology aids or hinders humans. It also discusses social and professional issues. Students generally accept the information and do not have to look for or investigate it.

Students can integrate concepts they already know with events they observe in the laboratory by using inquiry-based learning models to implement teaching materials in the classroom [28]. Inquiry learning can also help students convert their misconceptions into scientific concepts [29]. Inquiry-based learning is expected to make students more creative, innovative, and meaningful in their learning, resulting in improved biology learning achievement [30]. This is due to the fact that the inquiry learning process includes higher-level mental processes such as formulating problems, designing experiments, conducting experiments, collecting and analyzing data, and drawing conclusions [31]. Inquiry-based learning encourages students to think and work on their initiative and be objective, honest, open, and free to learn on their own [32].

Learning with inquiry gives students more opportunities to see knowledge in various meaningful contexts, encourages students to participate actively in learning, and makes students feel happier and more motivated throughout the learning process [33]. The integrated inquiry-based science teaching material aimed at training and developing concept mastery has advantages and is widely used in the learning process [34]. This is because students are expected to learn directly or independently in finding concepts using scientific procedures and the steps of the scientific method to train and develop an understanding of the scientific process, as well as indirectly train and develop critical thinking skills and creativity in problemsolving [35].

The guided inquiry model can improve students' conceptual mastery so that it is believed to show better concept mastery results [36]. The same statement states that the guided inquiry model is one way to develop knowledge by building concepts. Applying the guided inquiry learning model can provide a positive response to the learning activities carried out and improve students' understanding in learning. Learning questions can also help students build knowledge through the process of thinking and asking questions as well as a combination of games and eventually improve students' cognitive learning outcomes [37].

\section{CONCLUSION}

The ethnoscience integrated science teaching materials based on guided inquiry are feasible and effective in improving students' scientific literacy. This can be observed from the 
results of the feasibility test obtaining valid criteria and the results of the effectiveness test of the three schools getting an increase with high criteria.

\section{ACKNOWLEDGEMENT}

Many thanks to the Regional Development Research and Development Planning Agency with license number 070/674/02-BAPPEDA concerning research. Many thanks to the Rector, Director, and Head of the Postgraduate Study Program of Faculty of Mathematics and Natural Sciences, the University of Mataram, who have facilitated the completion of this research. Many thanks to the Lecturers (Prof. Agil Al Idrus, M.Si \& Dr. Abdul Syukur, M.Si) who guided this research to completion. Many thanks to the principals and partner teachers (State Junior High School 1 Pringgabaya, State Junior High School 4 Pringgabaya, and Islamic Junior High School NW Pringgabaya) who have enthusiastically facilitated this research, and to all those who have helped to carry out this research.

\section{REFERENCE}

[1] Ramdani, A., Syukur, A., Permatasari, I., \& Yustiqvar, M. (2021, July). Student Concepts' Mastery. In 5th Asian Education Symposium 2020 (AES 2020) (pp. 195-199). Atlantis Press

[2] Hastuti, P. W., Setianingsih, W., \& Anjarsari, P. (2020). How to develop student's scientific literacy through integration of local wisdom in Yogyakarta on science learning?. In Journal of Physics: Conference Series (Vol. 1440, No. 1, p. 012108). IOP Publishing.

[3] Supriyatman, S., \& Sukarno, S. (2014). Improving science process skills (SPS) science concepts mastery (SCM) prospective student teachers through inquiry learning instruction model by using interactive computer simulation. International Journal of Science and Research (IJSR), 3(2), 6-9.

[4] Ramdani, A., Syukur, A., Permatasari, I., \& Yustiqvar, M. (2021, July). Student Concepts' Mastery. In 5th Asian Education Symposium 2020 (AES 2020) (pp. 195-199). Atlantis Press.

[5] Tadesse, T., Manathunga, C. E., \& Gillies, R. M. (2018). Making sense of quality teaching and learning in higher education in Ethiopia: Unfolding existing realities for future promises. Journal of University Teaching \& Learning Practice, 15(1), 4.

[6] Wicaksono, I., \& Wasis, M. (2017). The effectiveness of virtual science teaching model (VS-TM) to improve student's scientific creativity and concept mastery on senior high school physics subject. Journal of Baltic Science Education, 16(4), 549.

[7] Zulhalifah., Aulia, J., Melita, A. S. \& Syukur, A. (2021). Pemanfaatan Nilai Ekologi Ekosistem Mangrove Sebagai Sumber Belajar
IPA di SMAN 3 Lembar. Jurnal Pengabdian Magister Pendidikan IPA, 4(2)

[8] Rahayu, W. E., \& Sudarmin, S. (2015). Pengembangan modul IPA terpadu berbasis etnosains tema energi dalam kehidupan untuk menanamkan jiwa konservasi peserta didik. Unnes Science Education Journal, 4(2)

[9] Andayani, Y., Purwoko, A. A., Jamaluddin, J., Makhrus, M., \& Harjono, A. (2020). Identifikasi Pemahaman Guru Tentang Pengembangan Perangkat Pembelajaran IPA SMP dengan Pendekatan Etnosain. Jurnal PEPADU, 1(2), 229-234.

[10] Shidiq, A. S. (2016). Pembelajaran sains kimia berbasis etnosains untuk meningkatkan minat dan prestasi belajar peserta didik. In Seminar Nasional Kimia dan Pendidikan Kimia (SNKPK) VIII (pp. 227-236). Surakarta: UNS.

[11] Arfianawati, S., Sudarmin, S., \& Sumarni, W. (2016). Model pembelajaran kimia berbasis etnosains untuk meningkatkan kemampuan berpikir kritis peserta didik. Jurnal Pengajaran MIPA, 21(1), 46-51.

[12] Damayanti, C., Rusilowati, A., \& Linuwih, S. (2017). Pengembangan model pembelajaran ipa terintegrasi etnosains untuk meningkatkan hasil belajar dan kemampuan berpikir kreatif. Journal of Innovative Science Education, 6(1), 116-128.

[13] Permatasari, I., Ramdani, A., \& Syukur, A. (2019). Pengembangan Bahan Ajar IPA Berbasis Inkuiri Terintegrasi Sets (Science, Environment, Technology And Society) pada Materi Sistem Reproduksi Manusia. Jurnal Pijar Mipa, 14(2), 74-78.

[14]Rahayu, W. E., \& Sudarmin, S. (2015). Pengembangan modul IPA terpadu berbasis etnosains tema energi dalam kehidupan untuk menanamkan jiwa konservasi peserta didik. Unnes Science Education Journal, 4(2)

[15] Khusniati, M. (2017). Local Wisdom-Based Science Learning Model through Reconstruction of Indigenous Science to Improve Student's Conservationist Character. Journal of Turkish Science Education, 14(3), 16-23.

[16] Sudarmin, Febu, R., Nuswowati, M., \& Sumarni, W. (2017). Development of Ethnoscience Approach in The Module Theme Substance Additive s to Improve the Cognitive Learning Outcome and Student's Entrepreneurship. Journal of Physics: Conference Series, 824(1).

[17] Gunstone, A. (2014). Developing Sustainable Education in Regional Australia. Melbourne: Monash University Publishing.

[18] Al Idrus, A., Ilhamdi, L., Mertha, I. G., Abidin, L. A. M., \& Yaqutunnafis, L. (2021). Konservasi Sumberdaya Alam Berwawasan Kearifan Lokal Melalui Sosialisasi Peningkatan 
Kesadaran Lingkungan Pada Masyarakat Desa Bagik Payung Timur, Lombok Timur. Jurnal Pengabdian Magister Pendidikan IPA, 4(3).

[19] Nurkhalisa, S., \& Ummayah, F. F. D. (2015). Etse-Module "The Benefits of Acidic Bases in Life" Ethnoscience Based Demak Society in the Utilisation of Lime. International Journal of Science and Research (IJSR), 6(7), 1396-1400.

[20] Rahayu, W. E., \& Sudarmin, S. (2015). Pengembangan modul IPA terpadu berbasis etnosains tema energi dalam kehidupan untuk menanamkan jiwa konservasi peserta didik. Unnes Science Education Journal, 4(2)

[21] Puspasari, A., Susilowati, I., Kurniawati, L., Utami, R. R., Gunawan, I., \& Sayekti, I. C. (2019). Implementasi Etnosains dalam Pembelajaran IPA di SD Muhammadiyah Alam Surya Mentari Surakarta. SEJ (Science Education Journal), 3(1), 25-31.

[22] Hidayani, S., Jamaluddin, J., \& Ramdani, A. (2021). Pemanfaatan Hasil Pengembangan Instrumen Untuk Penilaian Literasi Sains Peserta Didik Pada Mata Pelajaran IPA di SMPN 2 Mataram. Jurnal Pengabdian Magister Pendidikan IPA, 4(1).

[23] Pursitasari, I. D., Suhardi, E., Ardianto, D., \& Arif, A. (2019). Pengembangan bahan ajar bermuatan konteks kelautan untuk meningkatkan literasi sains siswa. Jurnal IPA \& Pembelajaran IPA, 3(2), 88-105.

[24]Zakaria, L. M. A., Purwoko, A. A., \& Hadisaputra, S. (2021). Penerapan Hasil Pengembangan Bahan Ajar Kimia Berbasis Masalah dengan Pendekatan Brain Based Learning Untuk Penilaian Keterampilan Berpikir Kritis Dan Literasi Sains Peserta Didik di SMAN 4 Praya. Jurnal Pengabdian Magister Pendidikan IPA, 4(1).

[25] Imansari, M., Sudarmin, S., \& Sumarni, W. (2018). Analisis literasi kimia peserta didik melalui pembelajaran inkuiri terbimbing bermuatan etnosains. Jurnal Inovasi Pendidikan Kimia, 12(2).

[26] Primayana, K. H., Lasmawan, I. W., \& Adnyana, P. B. (2019). Pengaruh Model Pembelajaran Kontekstual Berbasis Lingkungan Terhadap Hasil Belajar Ipa Ditinjau Dari Minat Outdoor Pada Peserta didik Kelas Iv. Jurnal Pendidikan dan Pembelajaran IPA Indonesia, 9(2), 72-79.

[27] Damayanti, C., Rusilowati, A., \& Linuwih, S. (2017). Pengembangan model pembelajaran ipa terintegrasi etnosains untuk meningkatkan hasil belajar dan kemampuan berpikir kreatif. Journal of Innovative Science Education, 6(1), 116-128.

[28] Ni'mah, S., Ulimaz, A., \& Lestari, N. C. (2018). Penerapan Bahan Ajar Berbasis Inkuiri Terbimbing Terhadap Pemahaman Konsep
Biologi Peserta didik SMP Di Banjarmasin Barat. Jurnal Biotek, 6(2), 120-130.

[29]Nana, N. (2020). Penerapan Model Pembelajaran Inkuiri Terbimbing untuk Mereduksi Miskonsepsi pada konsep Gerak Lurus Peserta didik SMA Kelas X. DIFFRACTION, 2(1), 44-51.

[30] Assriyanto, K. E., Sukardjo, J. S., \& Saputro, S. (2014). Pengaruh model pembelajaran berbasis masalah melalui metode eksperimen dan inkuiri terbimbing ditinjau dari kreativitas peserta didik pada materi larutan penyangga di SMA N 2 Sukoharjo tahun ajaran 2013/2014. Jurnal Pendidikan Kimia, 3(3), 89-97

[31] Amijaya, L. S., Ramdani, A., \& Merta, I. W. (2018). Pengaruh model pembelajaran inkuiri terbimbing terhadap hasil belajar dan kemampuan berpikir kritis peserta didik. Jurnal Pijar Mipa, 13(2), 94-99.

[32] Dewi, P. S. (2016). Perspektif Guru sebagai Implementasi Pembelajaran Inkuiri Terbuka dan Inkuiri Terbimbing terhadap Sikap Ilmiah dalam Pembelajaran Sains. Tadris: Jurnal Keguruan Dan Ilmu Tarbiyah, 1(2), 179-186.

[33] Umami, R., \& Jatmiko, B. (2013). Penerapan Model Pembelajaran Inkuiri dengan Pendekatan SETS (Science, Environment, Technology and Society) pada Pokok Bahasan Fluida Statis untuk Meningkatkan Keterampilan Berpikir Kritis Peserta didik Kelas XI SMA Negeri 1 Gedangan. Inovasi Pendidikan Fisika, 2(3).

[34] Syamsu, F. D. (2018). Pengembangan penuntun praktikum ipa berbasis inkuiri terbimbing untuk peserta didik smp peserta didik kelas vii semester genap. Bionatural: Jurnal Ilmiah Pendidikan Biologi, 4(2).

[35] Handayani, T. W. (2018). Peningkatan Pemahaman Konsep IPA Menggunakan Model Pembelajaran Inkuiri Terbimbing di SD. Edutainment, 6(2), 130-153.

[36] Leonor, J. P. (2015). Exploration of Conceptual Understanding and Science Process Skills : A Basis for Differentiated Science Inquiry Curriculum Model. International Journal of Information and Education Technology, 5(4), 255-259.

[37] Jundu, R., Tuwa, P. H., \& Seliman, R. (2020). Hasil belajar IPA Peserta didik SD di Daerah Tertinggal dengan penerapan model pembelajaran inkuiri terbimbing. Scholaria: Jurnal Pendidikan Dan Kebudayaan, 10(2), 103-111. 